\title{
Harmonization of Market Conditions in Provision of Freight Forwarding
}

\author{
Miloš Poliak ${ }^{1 *}$, and Patrícia Šimurková ${ }^{2}$ \\ ${ }^{1}$ University of Žilina, Faculty of Operation and Economics of Transport and Communications, \\ Department of Road and Urban Transport, Univerzitná 1, 01026 Žilina, Slovak Republic
}

\begin{abstract}
The paper deals with the issue of different market access for the transport procurement in the EU in context of open market of providing forwarding services. It highlights different requirements of market access in freight forwarding. The article proposes conditions of market access unification in freight forwarding based on analysis of the existing situation. It also refers to the different responsibility of freight forwarder depending on membership in the national associations of freight forwarders. The contribution analyses the limitation of liability in freight forwarding and shows differences in contract of freight forwarding for particular shipments by model examples. There is also pointed to the need for the development of uniform freight forwarding conditions in the EU.
\end{abstract}

\section{Introduction}

Freight forwarders play an important role in transport chain. They provide professional services in national and international transport. The basic task of every freight forwarder is procuring of transport and providing of advisory service for all modes of transport. Freight forwarders seek to ensure non-tariff discounts on behalf of customer. They check invoices for transportation outputs and the other expenditures, carry out all kinds of discounts and their direct debits and give it to the customer according to previously agreed principles. Forwarders also ensure claim damages or may, in agreement with the customer handle complaints directly [1]. Another important task is drawing up the calculation of transportation outputs, recommendation of the optimal transport route and determination of the optimal tariff declaration for transported goods. A freight forwarder operates a collection service, carries out national collection and distribution of shipments, and ensures completion, distribution of general cargo, storing, signing and repairing of packaging. They are also responsible for providing various benefits for all modes of transports for example the issuing of documents. A freight forwarder can carry out, in agreement with customer, customs clearance of consignments and can represent customer in customs procedures. Last but not least, he can provide legal aid to the customer in defending his interests in disputes with his partners [2].

*Corresponding author: milos.poliak@,fpedas.uniza.sk 
It follows that the role of freight forwarder is not easy and the freight forwarder has a high responsibility for his actions in these tasks. When ordering services, the customer expects to receive quality services which can be provided only by specialist.

Whereas the market access conditions in freight forwarding are significantly different in the EU, the aim of this paper is to highlight the importance of position of freight forwarder and define differences in market access. The aim of the paper is also suggest a way of harmonizing market access for freight forwarding in the EU.

The freight forwarding is not adjusted uniformly in the EU by common legislation in light of forwarding contract, for example like CMR Convention in the road transport. Given that the aim of this paper is also to point out different responsibilities of freight forwarders who conclude forwarding contracts under the national law and to propose a way of uniting responsibility $[3,4]$.

\section{Market access in freight forwarding in the selected countries}

Freight forwarding has unmistakable role in the providing of transport and logistics services in countries with developed market economy. Freight forwarding is providing transport or other activities related to the carriage under his own name, on his own responsibility and on behalf of third.

As the conditions of market access are not harmonized for freight forwarding in the EU, the aim of this paper is identify whether freight forwarders from the other selected countries have comparable conditions of market access. Access to the freight forwarding business is governed by national law. Because of this it is necessary to identify the specific national legislation of EU Member States by analysing market access in freight forwarding. Based on the analysis of national law which is available in [5] it is possible to divide the countries according to Table 1 .

Table 1. Comparison of requirements for market access in freight forwarding. Source: $[5,6]$

\begin{tabular}{|c|c|c|c|c|}
\hline Country & $\begin{array}{c}\text { Required } \\
\text { experience }\end{array}$ & $\begin{array}{l}\text { Required } \\
\text { education }\end{array}$ & $\begin{array}{l}\text { Financial } \\
\text { guarantee }\end{array}$ & $\begin{array}{l}\text { Unregulated } \\
\text { trade }\end{array}$ \\
\hline Belgium & yes & yes & yes & \\
\hline Bulgaria & & & & yes \\
\hline Croatia & & & & yes \\
\hline $\begin{array}{c}\text { Czech } \\
\text { Republic }\end{array}$ & & & & yes \\
\hline France & yes & yes & & \\
\hline Germany & & & & yes \\
\hline Netherlands & & & & yes \\
\hline Poland & yes & & yes & \\
\hline Portugal & yes & yes & yes & \\
\hline Austria & yes & yes & & \\
\hline Slovakia & yes & yes & & \\
\hline Spain & yes & & & \\
\hline Sweden & & & & yes \\
\hline Italy & yes & yes & yes & \\
\hline $\begin{array}{l}\text { Great } \\
\text { Britain }\end{array}$ & & & & yes \\
\hline
\end{tabular}

In the position of freight forwarder may be the company or a person who has no professional training or professional representation in seven of analysed countries, as Bulgaria, Croatia, Czech Republic, Germany, Netherlands, Sweden and the Great Britain. 
In these countries is the freight forwarding unregulated trade, it means any person who meets the general business conditions, can make business in freight forwarding. In the other analysed countries are different conditions.

The mandatory conditions for obtaining a business license in Belgium are experiences of the last six years and at least:

- five continuous years in a company holding a license,

- three years, if was met a 3-year training,

- two years, if was met a 3-year training or if the applicant holds a university diploma

- six months if the applicant passes a professional examination in forwarding or if has own certificate of professional competence in transport (additional test for specific faculties of freight forwarding).

Another condition is a financial guarantee in amount of $12394.68 €$ for the license, the integrity which is a proof of good moral conduct of public authorities and it is showing that the applicant did not commit any crime. The other duties include, for example, a certificate of professional experiences which is issued by person, who is assuring the daily management of the company.

In France, activity of freight forwarder is regulated by several conditions. The first condition is the registration in business register and second condition is the registration in a register of freight forwarder. The registration is conditional and is required qualification for profession and integrity. Requirement of registration is professional competence that is certified by the "Prefect of the regions". Conditions to achieve professional qualifications are the ownership level III diploma "Diplôme de niveau III $(\mathrm{Bac}+2)$ " and also major in transport. There it is also required at least 200 hours of management experience and successful completion of a special written examination. The applicant must demonstrate five consecutive working-years in a transport company but no more than three years before filing the application. The other condition is an integrity, which is defined by clean criminal record. A professional qualification is certified for those who have mastered either a written test, have a sufficient expertise or demonstrate related diplomas [5].

Freight forwarding services in Poland can be provided only to entrepreneurs who meet the prescribed conditions of required competence. Professional competence in Poland, which is proved by certificate of professional competence, is identical to the certificate of professional competence for the road transport. The certificate of professional competence must be at least one person from the management company or a person who is working in a company that is responsible for operating road transport operations. Entrepreneur who wants to provide services related to the acquisition or brokering transport, must demonstrate a minimum share capital $50000 €$.

In Portugal, the professional competence is a mandatory condition for obtaining a business license in freight forwarding, which is obtained through a special examination by National Committee for Transport. National Committee for Transport is the authority in the field of freight forwarding. The applicant must also meet financial guarantee which is demonstrated by capital in amount of $50000 €$ and a liability insurance in the amount of $100000 €$. Another important condition is to prove integrity. It means that the applicant has no criminal record for managers, board members, and technical directors [5].

In Austria, the applicant must meet the general conditions of business and professional competence. A technically competent person is one who has successfully completed the listed schools (transport, economic and law) and has one year of experience or passes the exam and has two years of experience in the field. The exam is organized annually by the Economic Chamber. The test consists of two parts. Written part of the exam includes as correspondence, drawing up documents, payments and lending, calculating performance, billing the customer and internal accounting evidence according to the special requirements of accounting. The oral part consists of 13 headings. 
Requirements for a freight forwarder in the Slovak Republic are established by Act no. 455/1991 Coll. On Trade Licensing. This act requires meeting criteria of specific conditions (in the form of professional competence) in addition to general business conditions by the applicant for freight forwarding. According to the Act no. 455/1991 Coll. on Trade Licensing is professionally qualified the applicant who has completed secondary education and has at least two years' experience in the field or a university degree in the field of study, and at least one year experience in the field. There are only general business conditions required in the case of transportation brokerage business by Trade Licensing. Brokering is classified as unregulated trade in the Slovak republic [7, 8].

\section{The responsibility of freight forwarder for the transportation procurement}

The freight forwarding business is regulated by Act no. 513/1991 Coll. Commercial Code and General Conditions of Consignment in the Slovak Republic. If it is based on the Act. 513/1991 Coll. Commercial Code (freight forwarders should not use any forwarding conditions) then each freight forwarder who breaches his obligations from the contractual relation contract is obligated to compensate damage caused to the other - to the customer. Except that the freight forwarder proves that the breach is caused by circumstances excluding his responsibility. These circumstances include for example floods, fires and the like. The responsibility is not excluded by an obstacle which occurred during the time when the obliged party was already in delay with the performance of its obligation or arose out if its economic situation. The effects excluding liability are limited to the period of time during which exists the obstacle, with which such effects are connected. It means that the freight forwarder, who does not have a particular responsibility in forwarding the modified conditions is liable under law no. 513/1991 Coll. Commercial Code to the full damage [9].

The scope of the responsibilities may be adjusted by General Conditions of Consignment. General Freight Forwarder's conditions are issued by Association of Logistics and Freight Forwarding of the Slovak Republic (hereinafter referred to as ALFF SR) and determinate responsibility of freight forwarder. Forwarding conditions ALFF SR are applicable to trade between the customers and freight forwarders in national and international freight forwarding, in case they become part of the contract of freight forwarding.

If the freight forwarder is responsible for damage, his duty to compensate is limited by General Freight Forwarder's conditions ALFF SR as follows:

- in case of damage which is occurred on the consignment during carriage by means of transportation or at the handling operations connected with carriage (at loading, transport, loading, unloading), the amount of damage is limited to $8.33 \mathrm{XDR}$ per $1 \mathrm{~kg}$ gross weight of the goods damaged, destroyed or lost, the maximum amount being 20 000 XDR per one case of damage,

- if the damage is caused by late delivery of the consignment, the freight forwarder's duty to compensate the damage is limited by the agreed amount of remuneration to the carrier.

- in case of storage the responsibility of the freight forwarder for the goods lost, damaged or destroyed is limited to the amount of:

- $3.925 \mathrm{XDR}$ per $1 \mathrm{~kg}$ of gross weight of the goods damaged, lost or destroyed; however, the maximum amount being 3925 XDR per one case of damage (one consignment),

- $19625 \mathrm{XDR}$, if damage is caused to the depositor (the customer) consists of the difference between required and actual state of the stored goods, 
- in cases of other damages the freight forwarder's duty to compensate the damage is limited to the amount of 20000 XDR per one case of damage.

This scope of responsibilities of freight forwarder is in force only if the reference for General Freight Forwarder's conditions ALFF SR is part of the contract of freight forwarding. If the contract is included with freight forwarder in another country, it is possible that part of the freight forwarding contract are forwarding conditions of other associations, which are setting different responsibilities. In the Table 2 is processed the overview of limitations of freight forwarders on the basis of general freight forwarding associations in the analysed countries. Table 2 shows the limitation of damaged or destroyed shipment per kilogram (if XDR value is converted also into euro in General Freight Forwarder's conditions) and per one case of damage.

Table 2. The limitation of responsibility of freight forwarder per kilogram of lost, damaged or destroyed shipment and per one case of damage. Source: $[5,6]$

\begin{tabular}{|c|c|c|c|c|}
\hline Country & $\mathbf{X D R} / \mathbf{k g}$ & $\mathbf{\epsilon} / \mathbf{k g}$ & $\mathbf{X D R}$ & $\boldsymbol{\epsilon}$ \\
\hline Slovakia & 8.33 & 9.36 & 20000 & 22480 \\
\hline Germany & & 5 & unlimited & \\
\hline Croatia & unlimited & unlimited & unlimited & unlimited \\
\hline Austria & - & 1.09 & - & 1090.09 \\
\hline Belgium & - & 5 & - & 25000 \\
\hline Italy & 8.33 & 9.36 & unlimited & unlimited \\
\hline Romania & 4 & 4,49 & 10000 & 11240 \\
\hline Estonia & 8.33 & 9.36 & 50000 & 56200 \\
\hline Netherlands & 4 & 4.49 & 10000 & 11240 \\
\hline Slovenia & 5 & 5.62 & 25000 & 28100 \\
\hline Poland & 2 & 2.25 & 50000 & 56200 \\
\hline Czech Republic & 8.33 & 9.36 & 20000 & 22480 \\
\hline $\begin{array}{c}\text { Norway, Finland, } \\
\text { Denmark, Sweden }\end{array}$ & 8.33 & 9.36 & 50000 & 56200 \\
\hline
\end{tabular}

The responsibility of freight forwarder is limited according to forwarding conditions and it can be in the amount from $1.09 € / \mathrm{kg}$ (Austria) to unlimited responsibility of freight forwarder (in Croatia). In the most of analysed countries is the responsibility of freight forwarder limited to the amount of 8.33 XDR per kilogram of damage or destroyed of goods as in the Slovak Republic (Slovakia, Italy, Estonia, the Czech Republic, Finland, Norway, Denmark and Sweden).

The responsibility of freight forwarder is also limited by the maximum responsibility in the case of damage, which is bounded from $1090.09 €$ per case of damage in Austria to unlimited liability (in Croatia, Italy). In the most analysed countries is the maximum responsibility of the freight forwarder in amount of 50000 XDR pre one case of damage, which corresponds to the value of $56200 €$.

\section{Proposal for amendment of market access for freight forwarding business}

Freight forwarder is responsible for a consignment by forwarding contract because transportation of shipment is carried out according to instructions of freight forwarder. Freight forwarder also appoints a carrier [10]. If there are requirements of professional competence and financial competence for a carrier directly by Regulation (EC) No. 
1071/2009 across the EU, freight forwarder should also demonstrate some professional competence. To enable market access in freight forwarding the content of professional competence should be given by internationally recognized course - Freight Forwarding Expert. Freight forwarding should be provided only by person who successfully completes the exam before the professional authority or demonstrates completed knowledge of the subjects which are subject for the freight forwarding course - Freight forwarding expert. These are the subjects: Introduction to freight forwarding, Maritime transport, Maritime containers, Multimodal transport, Air transport, Road transport; Rail transport; National and international transport by inland waterway; Customs procedures; Logistics, warehousing and distribution; Insurance; Dangerous goods; Safety and security; Information and Communication Technologies in freight forwarding.

The differences in EU market access should be deleted by adoption of rules. Freight forwarders, who are operating for the procurement of transport across the whole market, would have to meet the same requirements for market access.

In the analyse has been analysing a current state and it has been found that the forwarding contract is established accordance with national law and there is no unified responsibility of the carrier like, as in the road transport (CMR Convention), rail transport (COTIF Convention) or waterways transport (e.g. The Hague-Visby rules). Within the EU, or CLECAT, a convention should be accrued or at least the forwarding conditions that harmonize the level of freight forwarder's responsibility for damage. If we based on the average values, the responsibility would be limited to the level of:

- $5.10 € / \mathrm{kg}$ gross mass damaged, lost or destroyed goods

- $23000 €$ per shipment.

The resulting values of responsibility will be result of the negotiations of EU members or CLECAT but regardless the boundary is united responsibility very important.

\section{Conclusion}

In the EU, it is not a position of market access in freight forwarding uniformly regulated. Each country has its own specific conditions, which the applicant must meet. As the freight forwarder can provide his services in the EU, a potential customer receives a variety quality of services from freight forwarders $[11,12]$.

It follows from the above that, the requirements of market access in freight forwarding is needed to harmonize. It is because of that the freight forwarders do not provide their services in local markets but provides transport services through the EU market. If this were to happen, the market would have served the same quality freight forwarder and customers should be ensured that they get the service to the extent and quality they expect.

Within the procurement of transport, there is also the problem of different responsibilities of freight forwarders, depending on the conditions under which they operate forwarding. For the customer who is not specialized in transport, it can be unclear. As in the case of the CMR Convention for road transport it would be appropriate to harmonize the responsibility of freight forwarders operating on the Community market. The analysis points out significant differences in limitation of responsibility of freight forwarder. It should be noted that other differences are in defined circumstances, which exclude the liability of freight forwarder. Also the responsibility of freight forwarder is affected by the national rules governing trade relations in the country. 
This work was supported by the Slovak Research and Development Agency under the contract No. SK-PL-2015-0019 and VEGA no. 1/0143/17 POLIAK, M.: Increasing the competitiveness of Slovak carriers providing road transport services in the common market of the European Union.

This paper is supported by the research project "From horse-drawn railway to intermodal transport" within Visegrad Fund.

\section{References}

1. J. Gnap, et al., Freight Forwarding (Zasielatel'stvo), 2nd Edition (University of Zilina EDIS - Publishing, Slovak republic, 2011)

2. M. Poliak, Business in Freight Forwarding and Transport (Podnikanie v zasielatel'stve a doprave) (University of Zilina EDIS - Publishing, Slovak republic, 2011)

3. Z. Ř́ha, J. Tichý, The 19th International Scientific Conference, 388-391 (Kauno technologijos universitetas, 2015)

4. B. Caplan, The Economic Journal 112, 433-458 (2002)

5. T. Račeková, Proposal to unify market access conditions for freight forwarders in EU, (Diploma Thesis, M. Poliak - supervisor, University of Zilina, Slovak Republic, 2016)

6. D. Beňová,: Proposal of common freight forwarding conditions for CLECAT members, (Diploma Thesis, M. Poliak - supervisor, University of Zilina, Slovak Republic, 2016)

7. O. Cyprich, V. Konečný, K. Kilianova, PROMET - Traffic\&Transportation 25, 6, 533 $541(2013)$

8. M. Poliak, Journal of Economics 61, 2, 206-220 (2013)

9. M. Poliak, S. Semanova, A. Poliakova, Risk allocation in transport public service contracts, Ekonomski Pregled 66, 4, 384-403 (2015)

10. O. Stopka, L. Černá, V. Zitrický, Nase more 63, 3, 189-194 (2016), DOI: $10.17818 / \mathrm{NM} / 2016 / \mathrm{SI} 21$

11. I. Šimková, V. Knečný, S. Liščák, O. Stopka, Transport Problems 10, 113-124 (2015)

12. M. Poliak, A. Poliaková, Relation of social legislation in road transport on driver's work quality (TST, Wroclaw, Poland, 2015) 